\title{
Biomphalaria alexandrina snails as immunogens against Schistosoma mansoni infection in mice
}

\author{
Manal A Hamed/ ${ }^{+}$, Sanaa A Ali, Hanan F Aly, Nagy Saba El-Rigal, Maha Z Rizk \\ Therapeutic Chemistry Department, National Research Centre, Dokki, Cairo, Egypt
}

\begin{abstract}
Despite effective chemotherapy, schistosomiasis remains the second largest public health problem in the developing world. Currently, vaccination is the new strategy for schistosomiasis control. The presence of common antigenic fractions between Schistosoma mansoni and its intermediate host provides a source for the preparation of a proper vaccine. The objective of this paper is to evaluate the nucleoprotein extracted from either susceptible or resistant snails to protect against schistosomiasis. The vaccination schedule consisted of a subcutaneous injection of $50 \mu g$ protein of each antigen followed by another inoculation 15 days later. Analyses of marker enzymes for different cell organelles [succinate dehydrogenase, lactate dehydrogenase (LDH), glucose-6-phosphatase, acid phosphatase and 5'-nucleotidase] were carried out. Energetic parameters (ATP, ADP, AMP, phosphate potentials, inorganic phosphate, amino acids and LDH isoenzymes) were also investigated. The work was extended to record worm and ova counts, oogram determination in the liver and intestine and the histopathological pattern of the liver. The nucleoprotein of susceptible snails showed reduction in worm and ova counts by $70.96 \%$ and $51.31 \%$, respectively, whereas the nucleoprotein of resistant snails showed reductions of $9.67 \%$ and $16.77 \%$, respectively. In conclusion, we found that the nucleoprotein of susceptible snails was more effective in protecting against schistosomiasis.
\end{abstract}

Key words: Biomphalaria alexandrina - susceptible - resistant - Schistosoma mansoni - vaccine - nucleoprotein

Schistosomiasis is still a significant public health problem in developing countries. Currently, control of the disease by chemotherapeutic agents is impractical because of the common occurrence of reinfection after treatment (Silva et al. 2003). In addition, control through molluscicides is costly and creates the problem of distributing and accumulating the applied chemical agents (Hamed 2010). Recently, more efforts to induce immunity against schistosomiasis by vaccination have been directed at using either homologous or heterologous antigens (Bashtar et al. 2006, Hamed 2006). A protective vaccination represents an important strategy for long-term control of this disease. Due to the complex life cycle of schistosomes, different approaches to vaccine design may be necessary; such approaches include the polyvalent subunit vaccines (Xu et al. 2009).

The presence of common antigenic fractions between snail tissues and schistosomes directed many researchers to focus their work on the vaccination of the final host of Schistosoma mansoni with the constituents of its intermediate host (snails); these constituents include protein, nucleoprotein, lipid and carbohydrate (Tolba et al. 1995). These studies neglected to some extent the differences between resistant and susceptible snails. The relationship between snail host and schistosome is complex, involving a variety of genes associated with receptor recognition, cell adhesion, immune regulation, proteolytic enzymes and enzymes involved in detoxification reactions

+Corresponding author:manal_hamed@yahoo.com

Received 18 April 2010

Accepted 12 August 2010 (e.g., anti-oxidants) that are modulated by soluble parasite factor(s) in the snail host (Ittiprasert et al. 2010). A stress response, manifested by the modulation of genes encoding stress response proteins, such as heat shock protein 70 (Hsp 70), may also underlie the snail-host/parasite encounter (Zahoor et al. 2010). Ittiprasert et al. $(2009,2010)$ found that stress-related genes, Hsp 70 and reverse transcriptase were induced early and dramatically in susceptible snails, but not in resistant/non-susceptible ones. These differences between susceptible and resistant snails have encouraged many researchers to investigate the control of schistosomiasis by studying the inheritance of resistance to $S$. mansoni infection in Biomphalaria alexandrina snails (El Naga et al. 2010).

The aim of the present paper was to evaluate the immunogenic and biochemical effects of the nucleoprotein from either susceptible or resistant $B$. alexandrina snails on $S$. mansoni infection in mice. This was achieved by measuring worm and egg counts, oogram patterns in the liver and intestine, certain liver enzymes, energetic parameters and by screening essential and non-essential amino acids. The histopathological analysis of liver was also done to confirm the findings.

\section{MATERIALS AND METHODS}

Chemicals - All chemicals used in the present study were high analytical grade products from Sigma (USA), Merck (Germany), BDH (England), Riedel de Hàen (Germany) and Fluka (Switzerland).

Animals - Male Swiss albino mice of CDI strain (18$25 \mathrm{~g}$ ) were obtained from Theodor Bilharz Research Institute, Cairo, Egypt and maintained on water and stock commercial pellet diet ad libitum (El-Kahira Company for Oil and Soap). 
Ethics - Handling, anaesthetic and sacrifice procedures followed ethical guidelines approved by the Ethical Committee of the Federal Legislation, the National Institutes of Health Guidelines in the USA and the Medical Ethical Committee of the National Research Centre in Egypt.

Selection of susceptible and resistant snails - B. alexandrina snails were exposed to infection with 10 schistosome miracidia for each snail. All snails were examined for infection.

Antigen preparation - Nucleoproteins from susceptible and resistant snails were prepared according to the method of Nabih (1981) as follows. The shells were removed and soft tissues were collected in a pre-cooled grinder, homogenized with $5 \mathrm{~mL}$ of $5 \mathrm{M}$ sodium chloride solution at $-4^{\circ} \mathrm{C}$, left at $4^{\circ} \mathrm{C}$ for $12 \mathrm{~h}$ and then centrifuged at $4000 \mathrm{~g}$ for $15 \mathrm{~min}$. The nucleoprotein from tissue residue was re-extracted with $5 \mathrm{~mL}$ Krips Ringer buffer at $\mathrm{pH} 6.9$ for $24 \mathrm{~h}$ and it was then centrifuged at $4000 \mathrm{~g}$ for $15 \mathrm{~min}$. The supernatant was diluted 1:1 with diluted Krips Ringer buffer (1:10). The two extracts were combined, sterilized by adding diluted sodium merthiolate solution $(1: 10.000)$, heated in a water bath at $65^{\circ} \mathrm{C}$ for $25 \mathrm{~min}$ to ensure the absence of any bacterial contamination, cooled and stored at $-80^{\circ} \mathrm{C}$ until use.

Antigen administration protocol - The protein content of each extraction was determined by the Bradford method (1976). The antigen administration protocol was performed according to Maghraby et al. (2007). Each mouse was sensitized with a single subcutaneous injection of the selected antigen in a dose of $50 \mu \mathrm{g}$ protein. After 15 days, a second inoculation with the same antigen concentration was performed; thus, each mouse received a total dose of $100 \mu \mathrm{g}$ protein.

S. mansoni post challenge - Fifteen days after the last antigen injection, all vaccinated mice were infected with 80 cercariae of the $S$. mansoni Egyptian strain via the tail-immersion technique (Olivier \& Stirewalt 1952) for two months.

Experimental design - Mice were divided into six groups containing six mice each. Group 1: normal healthy control mice injected with one dose of $50 \mu \mathrm{L}$ of $5 \mathrm{M}$ phosphate buffer saline each week for two weeks; Groups 2, 3: normal healthy mice vaccinated with one of the two antigen preparations, as described in the immunization schedule above; Group 4: S. mansoni-infected mice; Groups 5, 6: S. mansoni-infected mice pre-vaccinated with $100 \mu \mathrm{g}$ of one of the two antigen preparations, with the same immunization regimens. All mice were sacrificed two months after the last injection.

Tissue homogenate - Liver tissue was homogenized in $0.9 \mathrm{~N} \mathrm{NaCl}(1: 10 \mathrm{w} / \mathrm{v})$ for the estimation of succinate dehydrogenase $(\mathrm{SDH})$, lactate dehydrogenase (LDH), glucose-6-phosphatase (G-6-Pase), acid phosphatase and 5'-nucleotidase. For the calculation of energetic parameters (ATP, ADP, AMP and Pi), $0.25 \mathrm{~g}$ of liver tissue was homogenized using $7 \%$ trichloroacetic acid for the extraction of adenosine nucleotides according to the method of Wijsman (1976).

\section{Parameter assays}

Enzyme determinations - Enzyme activities were evaluated using an end-point assay method. SDH: the reduction of flavin adenine dinucleotide is coupled with a reduction of tetrazolium salt as 2-p-iodophenyl-3-pnitrophenyl-5-phenyl tetrazolium chloride (INT); the produced formazan of INT is measured colorimetrically at $490 \mathrm{~nm}$ (Rice \& Shelton 1957). LDH: the reduction of nucleoside derived amino acids (NAD) was coupled with the reduction of tetrazolium salt with phenazine methosulfate serving as an intermediate election carrier; the produced formazan of INT was measured colorimetrically at $503 \mathrm{~nm}$ (Babson \& Babson 1973). The three enzymes, G-6-Pase, acid phosphatase and 5'-nucleotidase, were measured colorimetrically at $660 \mathrm{~nm}$ by measuring the inorganic phosphorus release following the methods of Swanson (1955), De Duve and Wattiaux (1956) and Bodansky and Schwartz (1963), respectively.

Energetic parameter evaluation - ATP was assayed following the procedure of Lamprecht and Trauschold (1974). ADP, AMP and ADP/AMP were assayed in a single assay system according to the method of Jaworek et al. (1974). The estimation of liver total protein was carried out according to the Bradford method (1976).

Calculation of phosphate potential (Po) - Po is an alternative index used to indicate the free energy status of the tissues and can be calculated from the concentration of ATP, ADP and inorganic phosphate (Pi) according to Van Waarde et al. (1990). Po = [ATP $] /[\mathrm{ADP}][\mathrm{Pi}]$.

$$
\begin{aligned}
& \text { Calculation of total adenylates }(T A)-\mathrm{TA}=\mathrm{ATP}+ \\
& \mathrm{ADP}+\mathrm{AMP} \text {. } \\
& \text { Calculation of adenylates energy charge }(\text { AEC })- \\
& \mathrm{AEC}=1 / 2[\mathrm{ADP}+\mathrm{ATP}] /[\mathrm{AMP}+\mathrm{ADP}+\mathrm{ATP}]
\end{aligned}
$$

LDH isoenzymes - The method of Dietz and Lubrano (1967) was adopted for the preparation of ultrathin layer polyacrylamide gel for the separation of $\mathrm{LDH}$ isoenzymes.

Amino acid assay - The amino acid composition of mouse liver was determined by the HPLC-Pico-Tag method according to Cohen et al. (1989) using a standard amino acid (Sigma, USA). The amino acids were quantified by comparing peak areas with corresponding amino acid standard solutions using the Spectra Physics Data System Program; the data were expressed as $\mu \mathrm{g} / \mathrm{mg}$ protein.

Worm counting - Worms were recovered by liver perfusion as described by Smithers and Terry (1965). The percent of reduction in worm number after challenge was calculated by the method of Tendler et al. (1986):

$$
\mathrm{P}=\mathrm{C}-\mathrm{V} / \mathrm{C} \times 100
$$

(P: percentage; $\mathrm{C}$ : mean number of parasites recovered from positive control (infected animals); V: mean number of parasites recovered from vaccinated animals).

Ova count - The number of ova per gram of tissue was counted by the method of Cheever et al. (1994), where

number of ova in $1 \mathrm{~g}$ of liver $=$ number of ova in $5 \mathrm{~mL} \mathrm{KOH}$

weight of liver in grams recorded before digestion 
Oogram determination - All viable and dead eggs were counted microscopically in the liver and intestine and classified according to the method of Pellegrino et al. (1962).

Histopathology - Representative slices from liver tissue were taken from the eviscerated animals and fixed in $10 \%$ buffer formalin. Paraffin-embedded sections $(4-\mu \mathrm{m}$ thick) were taken after fixation and slides were stained using haematoxylin and eosin by the method of Hirsch et al. (1997).

Statistical analysis - Analysis of data was carried out by one way analysis of variance with the Costat Computer Program.

\section{RESULTS}

Significant decreases in SDH and LDH enzyme activities were observed after $S$. mansoni infection (by $56 \%$ and $29.31 \%$, respectively), whereas levels of G-6Pase, acid phosphatase and 5'-nucleotidase showed significant increases (by $56 \%, 63.40 \%$ and $57.52 \%$, respectively) compared to normal healthy mice. Vaccination with nucleoprotein of susceptible $B$. alexandrina snails showed increased enzyme activities of SDH, LDH, G6-Pase, acid phosphatase and 5'-nucleotidase by $40 \%$, $15.10 \%, 43.77 \%, 44.26 \%$ and $23.76 \%$, respectively. Vaccination with nucleoprotein of resistant snails showed amelioration level by $38.66 \%, 12.55 \%, 35.73 \%, 35.01 \%$ and $20.18 \%$, respectively (Table I). In addition, protein content in infected mice showed a significant decrease by $23.84 \%$, whereas improvement in protein level was observed after immunization with the nucleoprotein of susceptible and resistant snails by $14.23 \%$ and $12.83 \%$, respectively (Table I). Normal healthy mice immunized with both nucleoproteins showed no significant changes for all enzymes under investigation, except for LDH, which showed a significant decrease.

We noticed a significant increase in ATP level in normal mice vaccinated with nucleoprotein extracted from either susceptible or resistant snails (by 6.08\% and $31.76 \%$, respectively) (Table II), whereas a significant decrease in ATP level was observed in infected mice (by $27.03 \%$ ). Vaccinated-infected groups showed significant ATP increases by $35.81 \%$ and $22.29 \%$ for susceptible and resistant snails, respectively. When we studied mice immunized with nucleoprotein from susceptible snails, mice immunized with nucleoprotein from resistant snails and mice infected with $S$. mansoni, significant increases of ADP level (by 7.14\%, 14.29\% and $435.71 \%$, respectively) and AMP level (by 62.5\%, 112.5\% and $99.08 \%$, respectively) were observed. Upon infection, vaccinated mice showed an improvement in ADP and AMP levels by $278.57 \%$ and $75 \%$, respectively, with nucleoprotein from susceptible snails, and by $321.43 \%$ and $50 \%$, respectively, with nucleoprotein from resistant snails. In addition, there was no significant change in $\mathrm{Pi}$ in normal mice vaccinated with nucleoprotein from either susceptible or resistant snails, whereas a significant reduction in $\mathrm{Pi}$ was observed in the infected group (by $41.63 \%)$. Vaccinated-infected mice showed a significant amelioration of $53.99 \%$ and $20.51 \%$ for nucleoproteins extracted from susceptible and resistant snails, respectively. At the same time, adenylates energy charge (AEC) showed no significant changes in normal vaccinated groups, whereas infected mice showed a significant reduction (by $22.22 \%$ ). Significant enhancements of $28.89 \%$ and $6.67 \%$ were observed in infected groups vaccinated with nucleoproteins from susceptible and resistant snails, respectively.

TABLE I

Effect of vaccination with nucleoprotein of susceptible and resistant snails on liver marker enzymes

\begin{tabular}{|c|c|c|c|c|c|c|}
\hline Parameters & Control & $\begin{array}{c}\text { Control } \\
\text { vaccinated }^{a}\end{array}$ & $\begin{array}{c}\text { Control } \\
\text { vaccinated }^{b}\end{array}$ & Infected & $\begin{array}{l}\text { Vaccinated } \\
\text { infected }^{a}\end{array}$ & $\begin{array}{l}\text { Vaccinated } \\
\text { infected }^{b}\end{array}$ \\
\hline Succinate dehydrogenase & $0.75 \pm 0.02^{c}$ & $0.73 \pm 0.02^{c}$ & $0.74 \pm 0.03^{c}$ & $0.33 \pm 0.02^{e}$ & $0.63 \pm 0.02^{d}$ & $0.62 \pm 0.03^{d}$ \\
\hline Lactate dehydrogenase & $109.91 \pm 3.33^{c}$ & $104.66 \pm 1.86^{d}$ & $104.99 \pm 1.25^{d}$ & $77.69 \pm 4.96^{f}$ & $94.29 \pm 3.31^{e}$ & $91.49 \pm 1.24^{e}$ \\
\hline Glucose-6-phosphatase & $57.11 \pm 4.28^{e}$ & $55.04 \pm 3.29^{e}$ & $56.69 \pm 5.83^{e}$ & $89.11 \pm 2.62^{c}$ & $64.11 \pm 3.09^{d}$ & $68.70 \pm 4.93^{d}$ \\
\hline Acid phosphatase & $15.25 \pm 1.24^{f}$ & $15.72 \pm 0.71^{f}$ & $16.14 \pm 0.88^{f}$ & $24.92 \pm 1.78^{c}$ & $18.17 \pm 0.87^{e}$ & $19.58 \pm 1^{d}$ \\
\hline 5'-nucleotidase & $186.14 \pm 4.12^{f}$ & $185.26 \pm 2.28^{f}$ & $184.43 \pm 3.08^{f}$ & $293.21 \pm 4.41^{c}$ & $248.97 \pm 2.71^{e}$ & $255.63 \pm 3.45^{d}$ \\
\hline Total protein & $70.25 \pm 3.50^{e}$ & $71.75 \pm 2.06^{c}$ & $73.75 \pm 4.11^{c}$ & $53.50 \pm 2.38^{e}$ & $63.50 \pm 1.73^{d}$ & $62.52 \pm 2.62^{d}$ \\
\hline
\end{tabular}

$a, b$ : nucleoprotein from susceptible and resistant snails, respectively; $c$-f: significance values at $\mathrm{p}<0.0001$. Data are means \pm standard deviation of six mice in each group. Data are expressed in $\mu \mathrm{mole} / \mathrm{min} / \mathrm{mg}$ protein. Total protein is expressed as $\mathrm{mg} / \mathrm{g}$ tissue. Statistical analysis is carried out using one way analysis of variance with Costat Computer Program. 
TABLE II

Effect of vaccination with nucleoprotein of susceptible and resistant snails on liver energetic parameters

\begin{tabular}{|c|c|c|c|c|c|c|}
\hline Parameters & Control & $\begin{array}{c}\text { Control } \\
\text { vaccinated }^{a}\end{array}$ & $\begin{array}{c}\text { Control } \\
\text { vaccinated }^{b}\end{array}$ & Infected & $\begin{array}{l}\text { Vaccinated } \\
\text { infected }^{a}\end{array}$ & $\begin{array}{l}\text { Vaccinated } \\
\text { infected }^{b}\end{array}$ \\
\hline ATP & $1.48 \pm 0.04^{f}$ & $1.57 \pm 0.102^{e}$ & $1.95 \pm 0.12^{d}$ & $1.08 \pm 0.01^{c}$ & $1.61 \pm 0.253^{e}$ & $1.41 \pm 0.09^{f}$ \\
\hline ADP & $0.14 \pm 0.01^{f}$ & $0.15 \pm 0.04^{e}$ & $0.16 \pm 0.01^{e}$ & $0.75 \pm 0.04^{d}$ & $0.36 \pm 0.01^{c}$ & $0.30 \pm 0.02^{c}$ \\
\hline AMP & $0.08 \pm 0.001^{d}$ & $0.13 \pm 0.01^{c}$ & $0.13 \pm 0.03^{c}$ & $0.17 \pm 0.01^{e}$ & $0.11 \pm 0.01^{c}$ & $0.13 \pm 0.02^{c}$ \\
\hline $\mathrm{Pi}$ & $13.26 \pm 1.36^{e f f}$ & $9.76 \pm 1.08^{e}$ & $15.47 \pm 2.11^{f}$ & $7.74 \pm 1.08^{g}$ & $14.90 \pm 1.55^{f}$ & $10.46 \pm 1.15^{e}$ \\
\hline $\mathrm{AEC}$ & $0.90 \pm 0.01^{d}$ & $0.79 \pm 0.02^{d}$ & $0.91 \pm 0.01^{d}$ & $0.70 \pm 0.001^{c}$ & $0.96 \pm 0.01^{d}$ & $0.76 \pm 0.20^{d}$ \\
\hline ATP/ADP & $10.57 \pm 1.76^{c}$ & $10.47 \pm 2.94^{c}$ & $12.19 \pm 2.19^{c}$ & $1.44 \pm 0.09^{d}$ & $4.47 \pm 0.22^{e}$ & $4.70 \pm 0.41^{e}$ \\
\hline ATP/AMP & $18.5 \pm 2.48^{d}$ & $12.07 \pm 1.73^{d}$ & $15 \pm 1.293^{d}$ & $6.35 \pm 0.28^{e}$ & $14.63 \pm 0.75^{d}$ & $10.85 \pm 0.38^{f}$ \\
\hline Po & $0.93 \pm 0.17^{e}$ & $1.25 \pm 0.29^{e}$ & $0.98 \pm 0.16^{e}$ & $0.14 \pm 0.02^{c}$ & $0.28 \pm 0.06^{f}$ & $0.49 \pm 0.07^{f}$ \\
\hline TA & $1.70 \pm 0.12^{d}$ & $1.84 \pm 0.09^{d}$ & $2.24 \pm 0.12^{d}$ & $2 \pm 0.04^{d}$ & $1.88 \pm 0.12^{d}$ & $1.84 \pm 0.64^{d}$ \\
\hline
\end{tabular}

$a, b$ : nucleoprotein from susceptible and resistant snails, respectively; $c$-g: significance values at $\mathrm{p}<0.0001$; Pi: inorganic phosphate; TA: total adenylates. All values present are the means \pm standard deviation of six mice in each groups and are expressed in $\mu \mathrm{mole} / \mathrm{g}$ tissue used/mg protein. Adenylates energy charge (AEC), ATP/ADP, ATP/AMP and phosphate potential (Po) are without dimension. Statistical analysis is carried out using one way analysis of variance with Costat Computer Program.

Measurements of ATP/ADP, ATP/AMP and Po showed no significant changes in all normal immunized groups, whereas a significant reduction was observed in the infected group (by $86.38 \%, 65.68 \%$ and $84.95 \%$, respectively). Vaccinated-infected groups showed significant enhancements in ATP/ADP, ATP/AMP and Po by $28.67 \%, 44.76 \%$ and $15.05 \%$, respectively, for susceptible snail nucleoprotein and by $30.84 \%, 24.32 \%$ and $37.63 \%$, respectively, for resistant snail nucleoprotein (Table II). TA showed no significant change in all groups under investigation.

With regards to LDH isoenzymes, no significant change was observed in normal immunized groups, whereas a significant increase was observed in $\mathrm{LDH}_{1}$ to $\mathrm{LDH}_{4}$ isoenzymes in infected mice (by $134.38 \%$, $78.43 \%, 171.63 \%$ and $53.02 \%$, respectively); $\mathrm{LDH}_{5}$ showed a significant reduction (by $26.24 \%$ ). The levels of $\mathrm{LDH}_{1}-\mathrm{LDH}_{5}$ isoenzymes showed significant amelioration by $119.79 \%, 65.14 \%, 147.14 \%, 56.87 \%$ and $24.09 \%$, respectively, in mice vaccinated with nucleoprotein from susceptible snails and by $125 \%, 49.89 \%$, $164.89 \%, 56.23 \%$ and $24.35 \%$, respectively, in mice vaccinated with nucleoprotein from resistant snails (Fig. 1, Table III).

Our results showed significant increases of amino acids in $S$. mansoni-infected mice in all fractions ex-

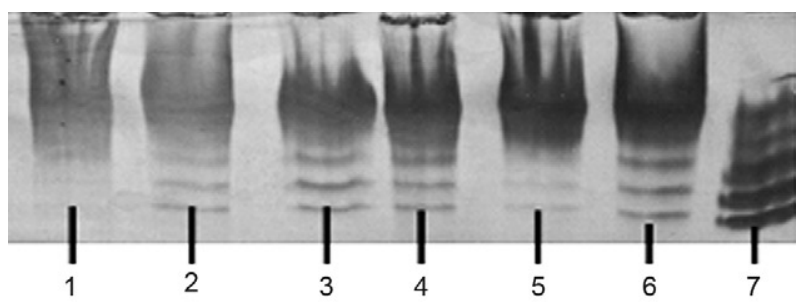

Fig. 1: lactate dehydrogenase isoenzymes pattern in normal liver and different immunized groups. Lane 1: infected liver; 2: normal liver vaccinated with susceptible snails nucleoprotein; 3: normal liver vaccinated with resistant snails nucleoprotein; 4: infected liver vaccinated with susceptible snails nucleoprotein; 5: infected liver vaccinated with resistant snails nucleoprotein; 6: normal control liver; 7: heart as a standard.

cept for methionine, which was significantly decreased relative to the control group. The vaccination of normal and post-infected mice with nucleoprotein from either susceptible or resistant snails showed significant increases in all amino acid fractions (Tables IV, V).

Table VI showed significant reductions in worm burden and ova count in the liver and intestine after vaccination with nucleoprotein from susceptible and 


\section{TABLE III}

Lactate dehydrogenase (LDH) isoenzymes pattern in liver tissue of normal, infected and vaccinated groups

\begin{tabular}{|c|c|c|c|c|c|c|}
\hline Parameters & Control & $\begin{array}{c}\text { Control } \\
\text { vaccinated }^{a}\end{array}$ & $\begin{array}{c}\text { Control } \\
\text { vaccinated }^{b}\end{array}$ & Infected & $\begin{array}{l}\text { Vaccinated } \\
\text { infected }^{a}\end{array}$ & $\begin{array}{l}\text { Vaccinated } \\
\text { infected }^{b}\end{array}$ \\
\hline $\mathrm{LDH}_{1}$ & $1.92 \pm 0.12^{d}$ & $1.90 \pm 0.17^{d}$ & $1.90 \pm 0.59^{d}$ & $4.50 \pm 0.13^{e}$ & $2.20 \pm 0.14^{d}$ & $2.10 \pm 1.23^{c}$ \\
\hline $\mathrm{LDH}_{2}$ & $4.59 \pm 0.56^{f}$ & $3.55 \pm 1.59^{f}$ & $4.55 \pm 0.99^{f}$ & $8.19 \pm 0.39^{e}$ & $5.20 \pm 1.33^{d}$ & $5.90 \pm 1.69^{d}$ \\
\hline $\mathrm{LDH}_{3}$ & $4.90 \pm 0.98^{e}$ & $4.77 \pm 1.88^{e}$ & $4.16 \pm 0.25^{e}$ & $13.31 \pm 1.51^{f}$ & $6.10 \pm 1.76^{d}$ & $5.23 \pm 0.59^{c}$ \\
\hline $\mathrm{LDH}_{4}$ & $10.92 \pm 1.55^{d}$ & $11 \pm 1.58^{d}$ & $11.29 \pm 0.38^{d}$ & $16.71 \pm 1.92^{e}$ & $10.50 \pm 1.79^{d}$ & $10.57 \pm 0.59^{d}$ \\
\hline $\mathrm{LDH}_{5}$ & $77.67 \pm 6.21^{d}$ & $78.78 \pm 8.91^{d}$ & $78.10 \pm 8.90^{d}$ & $57.29 \pm 6.71^{e}$ & $76 \pm 4.59^{d}$ & $76.20 \pm 11.20^{d}$ \\
\hline
\end{tabular}

$a, b$ : nucleoprotein from susceptible and resistant snails, respectively; $c$-f: significance values at $\mathrm{p}<0.0001$. All values are the means \pm standard deviation of three mice in each group and are expressed in a percent. Statistical analysis is carried out using one way analysis of variance with Costat Computer Program.

\section{TABLE IV}

Essential amino acid fractions in different mice groups vaccinated with nucleoprotein from susceptible and resistance snails

\begin{tabular}{|c|c|c|c|c|c|c|}
\hline Parameters & Control & $\begin{array}{c}\text { Control } \\
\text { vaccinate }^{a}\end{array}$ & $\begin{array}{c}\text { Control } \\
\text { vaccinated }^{b}\end{array}$ & Infected & $\begin{array}{c}\text { Infected } \\
\text { vaccinate }^{a}\end{array}$ & $\begin{array}{c}\text { Infected } \\
\text { vaccinate }^{b}\end{array}$ \\
\hline Threonine & $2.92 \pm 0.59^{g}$ & $32.50 \pm 1.53^{c}$ & $0.37 \pm 0.005^{h}$ & $8.66 \pm 0.68^{f}$ & $18.53 \pm 0.84^{e}$ & $22.45 \pm 1.46^{d}$ \\
\hline Valine & $3.09 \pm 0.79^{g}$ & $31.35 \pm 0.79^{c}$ & $3.55 \pm 0.60^{g}$ & $7.39 \pm 0.49^{f}$ & $15.72 \pm 0.69^{e}$ & $23.12 \pm 1.01^{d}$ \\
\hline Isoleucine & $1.86 \pm 0.70^{f}$ & $23.75 \pm 4^{c}$ & $3.64 \pm 0.44^{e, f}$ & $4.84 \pm 0.70^{e}$ & $12.33 \pm 0.78^{d}$ & $12.27 \pm 1.13^{d}$ \\
\hline Leucine & $3.61 \pm 0.65^{g}$ & $37.55 \pm 1.32^{c}$ & $7.78 \pm 0.57^{f}$ & $7.99 \pm 0.48^{f}$ & $18.16 \pm 0.70^{e}$ & $25.96 \pm 0.84^{d}$ \\
\hline Phenylalanine & $0.60 \pm 0.15^{g}$ & $18.99 \pm 0.59^{c}$ & $0.63 \pm 0.04^{g}$ & $4.24 \pm 0.51^{f}$ & $8.64 \pm 0.69^{e}$ & $15.75 \pm 0.85^{d}$ \\
\hline Histidine & $4.03 \pm 0.74^{g}$ & $28.43 \pm 0.76^{c}$ & $9.22 \pm 0.47^{f}$ & $8.78 \pm 0.58^{f}$ & $15.17 \pm 0.54^{e}$ & $21.77 \pm 0.98^{d}$ \\
\hline Lysine & $4.58 \pm 0.65^{h}$ & $43.67 \pm 1.79^{c}$ & $22.98 \pm 0.71^{e}$ & $10.53 \pm 0.54^{g}$ & $18.16 \pm 0.70^{f}$ & $42.18 \pm 1.94^{d}$ \\
\hline Methionine & $10.56 \pm 0.61^{e}$ & $12.34 \pm 0.81^{d}$ & $16.54 \pm 0.59^{c}$ & $2.34 \pm 0.55^{h}$ & $7.62 \pm 0.58^{g}$ & $8.34 \pm 0.41^{f}$ \\
\hline
\end{tabular}

$a, b$ : nucleoprotein from susceptible and resistant snails, respectively; $c-h$ : percentage change between groups at $\mathrm{p} \leq 0.0001$. Free amino acid fractions are expressed in $\mu \mathrm{g} / \mathrm{mg}$ protein. Data are expressed as mean \pm standard deviation of three reading for each group. Statistical analysis is carried out using one way analysis of variance with Costat Computer Program.

resistant snails. Vaccination with nucleoprotein from susceptible snail resulted in reductions of $70.96 \%$, $51.31 \%$ and $79.09 \%$, respectively, whereas vaccination with nucleoprotein from resistant snails resulted in reductions of $9.67 \%, 16.77 \%$ and $22.93 \%$, respectively.
Table VII shows that the oogram pattern in mice vaccinated with nucleoprotein from susceptible snails showed an increase of dead and immature ova by $62.5 \%$ and $17.94 \%$, respectively and a reduction in mature ova by $22.64 \%$. Vaccination with nucleoprotein from resis- 
TABLE V

Non essential amino acid fractions in different mice groups vaccinated with nucleoprotein from susceptible and resistant snails

\begin{tabular}{|c|c|c|c|c|c|c|}
\hline Parameters & Control & $\begin{array}{c}\text { Control } \\
\text { vaccinate }^{a}\end{array}$ & $\begin{array}{c}\text { Control } \\
\text { vaccinated }^{b}\end{array}$ & Infected & $\begin{array}{c}\text { Infected } \\
\text { vaccinate }^{a}\end{array}$ & $\begin{array}{c}\text { Infected } \\
\text { vaccinate }^{b}\end{array}$ \\
\hline Aspartic acid & $2.86 \pm 0.57^{f}$ & $35.65 \pm 2.1^{c}$ & $1.93 \pm 0.34^{f}$ & $16.45 \pm 0.76^{e}$ & $17.06 \pm 0.37^{e}$ & $26.33 \pm 1.69^{d}$ \\
\hline Serine & $4.86 \pm 0.58^{g}$ & $44.51 \pm 2.38^{c}$ & $3.19 \pm 0.32^{g}$ & $18.02 \pm 0.90^{f}$ & $29.83 \pm 3.73^{e}$ & $37.19 \pm 1.97^{d}$ \\
\hline Glutamic acid & $10.30 \pm 0.92^{g}$ & $73.70 \pm 1.59^{c}$ & $6.38 \pm 0.43^{h}$ & $31.97 \pm 1.47^{f}$ & $37.02 \pm 0.79^{e}$ & $57.88 \pm 1.35^{d}$ \\
\hline Glycine & $4.86 \pm 0.78^{g}$ & $31.97 \pm 1.82^{c}$ & $6.12 \pm 0.76^{g}$ & $15.27 \pm 0.39^{f}$ & $22.17 \pm 1.19^{e}$ & $24.68 \pm 0.90^{d}$ \\
\hline Alanine & $10.94 \pm 0.72^{g}$ & $41.82 \pm 1.01^{c}$ & $6.53 \pm 0.56^{h}$ & $18.93 \pm 0.80^{f}$ & $23.42 \pm 1.94^{e}$ & $32.44 \pm 1.49^{d}$ \\
\hline Tyrosine & $0.69 \pm 0.13^{e}$ & $7.61 \pm 0.77^{d, e}$ & $5.21 \pm 0.51^{e}$ & $4.14 \pm 0.44^{e}$ & $19.39 \pm 5.23^{c}$ & $12.98 \pm 0.79^{c, d}$ \\
\hline $\mathrm{NH}_{4}^{+}$ & $73.84 \pm 2.54^{d}$ & $38.15 \pm 0.61^{e}$ & $10.55 \pm 0.82^{h}$ & $92.69 \pm 1.93^{c}$ & $43.25 \pm 1.86^{e}$ & $34.69 \pm 0.82^{g}$ \\
\hline Proline & $32.74 \pm 1.79^{h}$ & $230.3 \pm 15.34^{c}$ & $44.50 \pm 2.8^{g}$ & $112.2 \pm 1.54^{f}$ & $130.55 \pm 3.36^{e}$ & $203.07 \pm 9.0^{d}$ \\
\hline
\end{tabular}

$a, b$ : nucleoprotein from susceptible and resistant snails, respectively; $c$-g: percentage change between groups at $\mathrm{p} \leq 0.0001$. Free amino acid fractions are expressed in $\mu \mathrm{g} / \mathrm{mg}$ protein. Data are expressed as mean \pm standard deviation of three reading for each group. Statistical analysis is carried out using one way analysis of variance with Costat Computer Program.

TABLE VI

Number of worm burden and ova count in vaccinated mice with nucleoprotein of susceptible and resistance Biomphalaria alexandrina snails

\begin{tabular}{|c|c|c|c|c|c|}
\hline Parameters & Infected & $\begin{array}{c}\text { Susceptible } \\
\text { nucleoprotein }\end{array}$ & $\begin{array}{c}\text { Resistant } \\
\text { nucleoprotein }\end{array}$ & \multicolumn{2}{|c|}{$\begin{array}{c}\text { Reduction } \\
\%\end{array}$} \\
\hline Worm count & $31 \pm 4.47^{c}$ & $9 \pm 2.31^{e}$ & $28 \pm 6.37^{d}$ & $70.96^{a}$ & $9.67^{b}$ \\
\hline Ova count (liver) & $14.37 \pm 4.6^{c}$ & $6.99 \pm 3.51^{e}$ & $11.96 \pm 0.91^{d}$ & $51.31^{a}$ & $16.77^{b}$ \\
\hline Ova count (intestine) & $27.09 \pm 15.57^{c}$ & $5.66 \pm 4.6^{e}$ & $20.87 \pm 3.71^{d}$ & $79.09^{a}$ & $22.93^{b}$ \\
\hline
\end{tabular}

$a$-e: significance values at $\mathrm{p}<0.0001$. Worm count is expressed as mean \pm standard deviation (SD) and ova count is expressed as $($ mean $\pm \mathrm{SD}) \times 10^{3}$ of six mice in each group. Worm and ova count are expressed in one gram of liver or intestine tissue. Statistical analysis is carried out using one way analysis of variance with Costat Computer Program.

tant snails showed an increase of dead and immature ova by $25 \%$ and $23.07 \%$, respectively, and a reduction in mature ova by $28.30 \%$.

Normal healthy mice did not show histopathological changes (Fig. 2A-C). In the infected group, hepatic granulomas were seen with two or more ova that were centrally placed (Fig. 3A, B). Eggs were observed in the liver tissues of the vaccinated animals with minimal infiltration as compared to the positive control (infected group). The granulomas appeared to be of the florid type (Fig. 3C). The cells around the granulomas consisted of a few lym- phocytes, eosinophils, epithelioid cells and many macrophages. In the immunized group, destruction of the liver tissue around the dead ova was seen with relatively small granulomas (Fig. 3D) and associated with a significant reduction in egg production and total worm load (Fig. 3E).

\section{DISCUSSION}

The host tissue is greatly involved in the phenomenon of parasite compatibility/incompatibility because the parasite depends on the host as a source of metabolites for survival; thus, the impact on the host metabolism is enor- 
TABLE VII

Oogram pattern in intestine of vaccinated mice with nucleoprotein of susceptible and resistance Biomphalaria alexandrina snail

\begin{tabular}{lccc}
\hline Ova & Infected & $\begin{array}{c}\text { Susceptible } \\
\text { nucleoprotein }\end{array}$ & $\begin{array}{c}\text { Resistance } \\
\text { nucleoprotein }\end{array}$ \\
\hline Dead & $8 \pm 1.89^{c}$ & $\begin{array}{c}13 \pm 2.22^{a} \\
(+62.5)\end{array}$ & $\begin{array}{c}10 \pm 2.75^{b} \\
(+25)\end{array}$ \\
Immature & $39 \pm 2.78^{c}$ & $\begin{array}{c}46 \pm 1.93^{b} \\
(+17.94)\end{array}$ & $\begin{array}{c}48 \pm 1.60^{a} \\
(+23.07)\end{array}$ \\
Mature & $53 \pm 2.03^{a}$ & $\begin{array}{c}41 \pm 3.65^{b} \\
(-22.64)\end{array}$ & $\begin{array}{c}38 \pm 3.12^{c} \\
(-28.30)\end{array}$ \\
\hline
\end{tabular}

$a-c$ : significance values at $\mathrm{p}<0.0001$. Ova count is expressed as (mean \pm standard deviation) $x 10^{3}$ of six mice in each group. Ova count is expressed in one gram of intestine tissue. Values between brackets are percentage changes as compared to infected group. Statistical analysis is carried out using one way analysis of variance with Costat Computer Program.

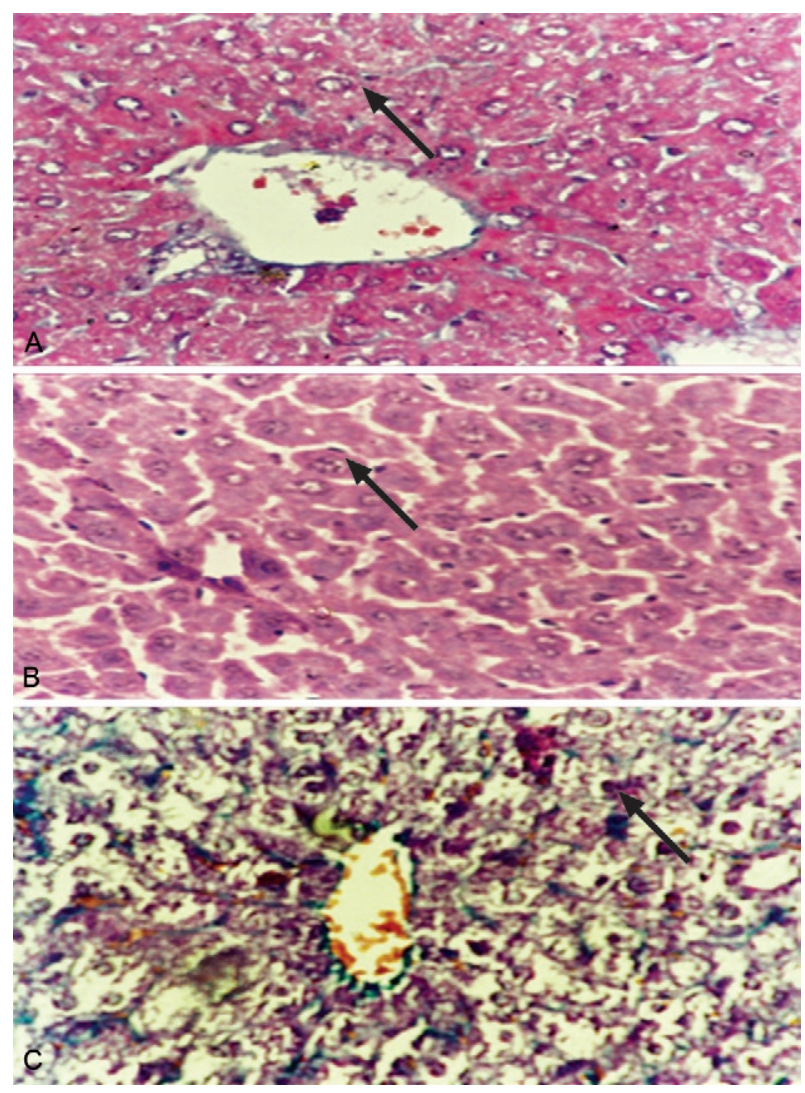

Fig. 2: sections through mice liver stained with haematoxylin and eosin. A: normal liver (200X); B: normal liver vaccinated with resistance snails nucleoprotein (400X); C: normal liver vaccinated with susceptible snails nucleoprotein (400X). Arrows show normal hepatic lobules formed of radially arranged cords of normal liver cells radiated from the central vein to the periphery of the lobule. mous. The host, in turn, uses a complex network of interactions and free radical weapons against the parasite. In the case of schistosomiasis, these defence mechanisms succeed in encapsulating or eliminating the parasites in resistant snails but fail to deal with them in susceptible snails due to differences in the levels of endogenous oxidant enzymes (Mahmoud \& Rizk 2004). This difference between susceptible and resistant snails may lead to different responses by the main host after vaccination and different degrees of protection from the parasites.

The present study recorded a significant decrease in SDH activity in S. mansoni-infected mice. This is in agreement with the studies by Hamed and Hetta (2005) and Bashtar et al. (2006), which found the same results
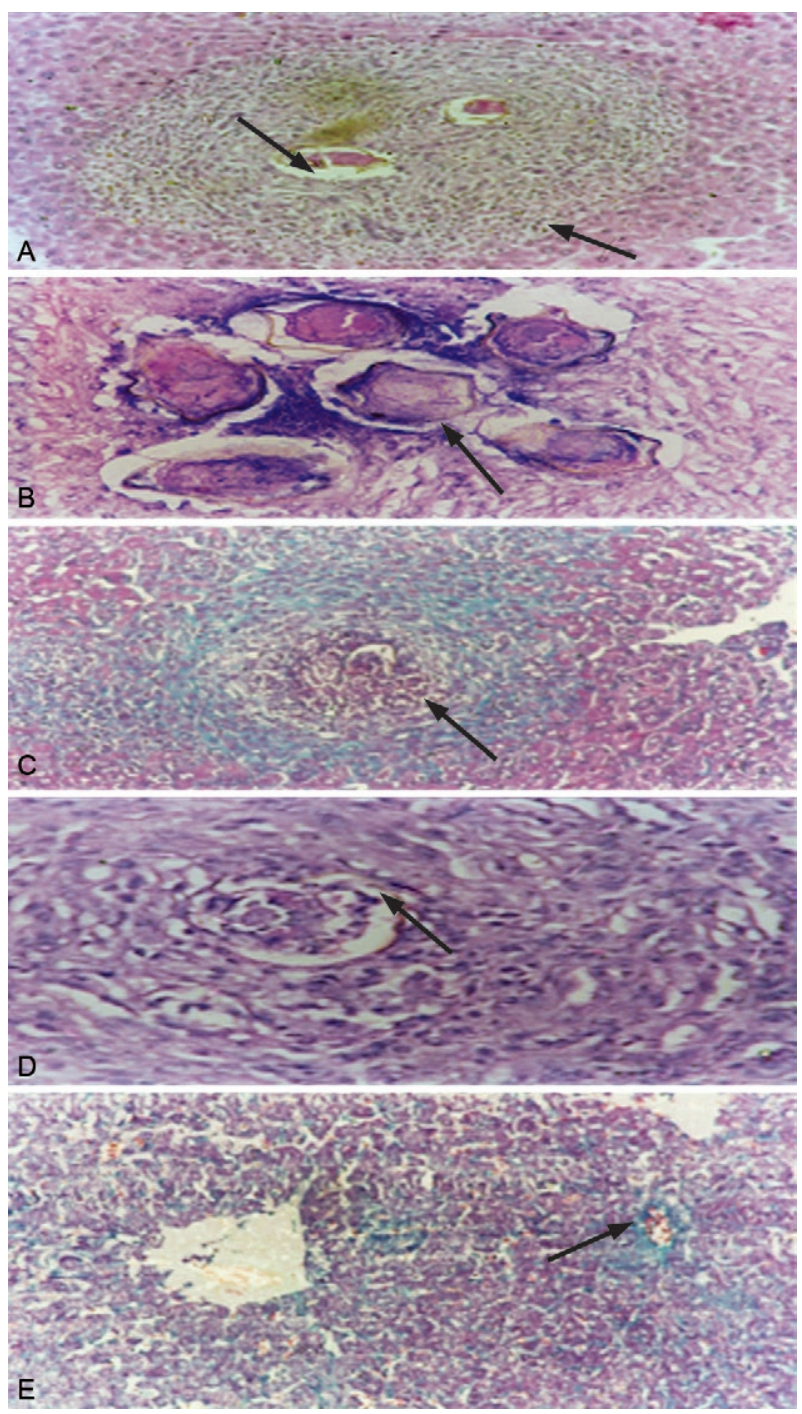

Fig. 3: sections through mice liver stained with haematoxylin and eosin. A, B: infected liver (100X and 400X, respectively); C, D: infected liver vaccinated with resistance snails nucleoprotein (100X and 200X, respectively); E: infected liver vaccinated with susceptible snails nucleoprotein (200X). Arrows show multiple granulomatous lesions and focal areas of necrosis with brownish black pigmentation representing cells infiltration. 
in bilharzial infection associated Schistosoma toxins that accumulate with the mitochondrial fraction and affect the enzyme activity. SDH is the marker enzyme of the mitochondria (el Gowhary 1993), so any changes in the enzyme activity would be accompanied by changes in the mitochondria. This was confirmed by the same authors, who noticed that mitochondria appeared swollen with fewer cristae and pale matrix in the liver cells of mice infected with S. mansoni. The mitochondrial changes could originate from the relative anoxia and irritation caused by toxic or metabolic products of adult worm and/or eggs; thus, by inhibiting mitochondrial oxidation and limiting oxygen amount, the activities of both SDH and Krebs cycle enzymes are repressed (Ahmed \& Gad 1995).

The observed decrease in LDH enzyme activity was due to the following: an increase in anaerobic glycolysis, the provision of energy, the inhibition of Kreb's cycle, a decrease in the NAD/NADH ratio due to the inhibition of mitochondrial oxidation, which favours the conversion of pyruvate to lactate, an increase in the metabolic activity of infected liver tissues due to associated inflammation lesions, a decrease in hepatic blood flow, a decrease in the utilization efficiency of other energy sources such as fat and proteins and the worms themselves, which depend on anaerobic glycolysis as the main source of energy production (Ahmed \& Gad 1995).

The observed increase in G-6-Pase activity after schistosomal infection was attributed to the proliferation and dilation of rough and smooth endoplasmic reticulum, as evidenced by the increased number of ribosomes and the proliferation and dilation of microsomal membranes. Because G-6-Pase is usually located here, it is considered a microsomal marker enzyme. This alteration in the endoplasmic reticulum leads to elevation of cytosolic calcium, which can trigger the conversion of phosphorylase $\mathrm{b}$ (inactive form) to phosphorylase a (active form); phosphorylase a degrades glycogen into glucose (Hamed \& Hetta 2005).

Mice infected with $S$. mansoni showed a significant increase in acid phosphatase enzyme activity. This elevation in acid phosphatase activity may be due to increased tissue catabolism resulting from increased worm and egg toxins from the infection. Acid phosphatase is a lysosomal marker enzyme (Frederiks \& Marx 1988) and all lysosomal enzymes are activated in conditions characterized by increased tissue catabolism and aberration of the lysosomes. This is in accordance with Jones and Bogitsh (1979), who histochemically found an increase in the number of mature lysosomes in the liver cells of mice after S. mansoni infection.

The increase in the 5'-nucleotidase enzyme activity after infection may be due to enhancement of the active transport process through the plasma membrane. This enzyme is localized to the bile canalicular and sinusoidal plasma membrane of the liver parenchymal cells (Frederiks \& Marx 1988). These results were confirmed by El-Aasar et al. (1989), who demonstrated histochemically that the sinusoids in the livers of infected mice showed an increased 5'-nucleotidase enzyme activity.
Reduction in ATP level, accompanied by increases in ADP and AMP concentrations, could easily be correlated with the aerobic-anaerobic transition induced by the developing parasites (Tielens et al. 1994). El-Ansary et al. (2001) added additional support to the present finding by demonstrating that the significant ATP depletion during $S$. mansoni infection, which is a physiologically stressful condition, leads to the elevation in ATP hydrolyzing pathways. Infection is also accompanied by a decrease in AEC, which may be attributed to a marked depletion in the level of phosphoarginine, an important player in buffering the changes in ATP, by serving as a metabolic pool of $\mathrm{Pi}$ for the transphosphorylation of ADP to ATP (Mantawy et al. 2004). Chapman and Atkinson (1973) reported that AEC values below 0.55 are apparently incompatible with the maintenance of the minimal level of homeostasis required for viability. Thus, the decreases in AEC in the livers of infected mice in this study are still within the non-stressed range and, hence, permit recovery.

The significant reduction in the Pi concentration despite the reduced level of ATP could be explained by the fact that, when liver is subjected to metabolic stress, a large amount of phosphate is trapped due to the presence of an abnormally high level of phosphoryl acceptor (Van Waarde et al. 1990).

The ATP/AMP ratio reflects the cell energy requirement and the rate of ATP utilization. Hence, cells that require severe changes in the rate of glycolysis need energy with a high ATP/AMP ratio (Dehn \& Schirf 1986). The ATP/ADP ratio revealed that the energy utilization reaction was higher than the energy-generating reaction in the infectious state and, in turn, this could confirm the impairment of oxidative phosphorylation in the liver and reduced metabolism (Tornheim \& Lowenstein 1974). The lower ATP/AMP ratio in infected mice revealed that although glycolytic flux was initiated to compensate the inhibition of Krebs cycle, the glycolytic change was insufficient because mice are extremely aerobic animals and cannot survive long in anaerobic conditions. The significant increase in Po during the period of infection confirmed the inhibition of Krebs cycle enzymes and the impairment of electron transport chain (Tielens et al. 1994).

With respect to TA, no significant change was observed in any of the studied groups. This finding is in accordance with the study by Ivanovici (1980) reporting that, during stress, significant reductions in ATP level did not co-vary with significant changes in TA levels. This could be attributed to the significant elevation of both AMP and ADP and the changes in the adenylate pool were not consistent with the lower AEC ratio.

$\mathrm{LDH}_{4}$ and $\mathrm{LDH}_{5}$, two of the most predominant isoenzymes in liver, were markedly affected during parasitic infection. $\mathrm{LDH}_{5}$ 's role in anaerobic glycolysis is reduced and this reduction may explain the false higher contribution of $\mathrm{LDH}_{1}$ and $\mathrm{LDH}_{2}$, which are involved in aerobic respiration. This is confirmed by the study of Hamed and Hetta (2005). In addition, Maly and Toranelli (1993) found that $\mathrm{H}$-monomer is supposed to be principally in- 
volved in the oxidation of lactate and should therefore be predominant in tissues with a high oxygen supply. In contrast, the $\mathrm{M}_{4}$ isoform and other isoforms rich in $\mathrm{M}$ subunits are geared toward the reduction of pyruvate and should be predominant in tissues that are subjected to more anaerobic conditions.

Levels of different amino acids are affected during infection. Threonine balances the protein level in the body and promotes the immune system. It aids in the synthesis of glycine and serine, two amino acids that help in the production of collagen, elastin and muscle tissue. It also speeds up wound healing after injury by boosting the immune system. Threonine, in combination with the amino acids aspartic acid and methionine, helps liver digest fat and fatty acids, a process that reduces the accumulation of fat in the liver. An accumulation of fat negatively affects the functions of liver. Histidine is important for the synthesis of red and white blood cells. Alanine removes toxic substances released from the breakdown of muscle proteins during intensive exercise. Glutamine and aspartic acid aid the functioning of all cells, RNA and DNA (the carriers of genetic code). Additional benefit of aspartic acid is the protection of the liver from damages that can be caused by excess ammonia in the bloodstream. Serine aids in the synthesis of proteins in immune system. Proline plays a role in intracellular signaling. In the present study, levels of all of these amino acids increased in all groups as compared to the control group. Tanabe et al. (1991) suggested that the $S$. mansoni egg granulomas contain a factor(s) that may be responsible for the elevation of free 1-proline content in the fibrotic liver. It has been suggested that the concentration of free amino acids in liver tissues can be a sensitive tool for determining the effect of antigen in control and infected animals (Mente et al. 2003).

The present results showed improvement of most biochemical parameters under investigation. This improvement due to vaccination was confirmed by the observed decrease in worm burden, ova count and its distribution pattern in the liver and intestine. This reduction may be due to the effect of the selected antigens on the fecundity state of the female worms.

The histopathological picture of the livers revealed alteration of the normal hepatic lobe architecture characterized by heavy cellular infiltration in the liver of infected mice, fibrous exudation and infiltration of eosinophils and mononuclear cells. The most characteristic lesions were marked by the presence of important fibroblastic tissue and the atrophy of the lobules (Frontera et al. 2003). Granuloma formation results from a delayed hypersensitivity response generated by the host against antigens secreted by the eggs of parasite (Ali \& Hamed 2006). Parasitic granulomas in the liver of infected animals with a central area of eosinophils, lymphocytes and macrophages were surrounded by a capsule of connective tissues and fibroblasts (El-Banhawey et al. 2007).

In the present study, nucleoprotein antigen has a dual function to reduce the worm and ova count and to reduce the number and size of liver granulomas. This type of antigen has been suggested to play a significant role in cell activation and the modulation of granulomatous hypersensitivity.
In conclusion, nucleoproteins of susceptible and resistant Biomphalaria snails protect against $S$. mansoni infection in mice through reduction in worm count, egg lodge, liver enzymes, liver energetic parameters and liver histopathology; however, the nucleoprotein of susceptible snails showed the most potent effect. Further examinations of the nucleoprotein constituents of susceptible and resistant snails must be performed to identify the specific target responsible for protection against infection.

\section{REFERENCES}

Ahmed SA, Gad MZ 1995. Effect of schistosomal infection and its treatment on some key enzymes of glucose metabolism in mice livers. Arzneimittelforschung 45: 1324-1328.

Ali SA, Hamed MA 2006. Effect of Ailanthus altissima and Zizyphus spina-christi on bilharzial infestation in mice: histological and histopathological studies. J Appl Sci 6: 1437-1446.

Babson AL, Babson SR 1973. Kinetic colorimetric measurement of serum lactate dehydrogenase activity. Clin Chem 19: 766-769.

Bashtar A, Ahmed SA, Soliman AM, Hamed MA 2006. Biochemical studies on hepatocytes after immunization of mice with schistosomal worm and egg antigens. Asian J Biochem 1: 224-235.

Bodansky O, Schwartz MK 1963. Comparative effects of L-histidine on the activities of 5'-nucleotidase and alkaline phosphatase. J Biol Chem 238: 3420-3427.

Bradford MM 1976. A rapid and sensitive method for the quantitation of microgram quantities of protein utilizing the principle of protein-dye binding. Anal Biochem 72: 248-254.

Chapman AG, Atkinson DE 1973. Stabilization of adenylate energy charge by the adenylate deaminase reaction. $J$ Biol Chem 248 : 8309-8312.

Cheever AW, Mosimann JE, Deb S, Cheever EA, Duvall RH 1994. Natural history of Schistosoma mansoni infection in mice: egg production, egg passage in the feces and contribution of host and parasite death to changes in worm numbers. Am J Trop Med Hyg 50: $269-280$

Cohen SA, Meyes M, Tarvin TL 1989. The Pico-Tag method: a manual of advanced techniques for amino acid analysis, Millipore Corporation, Milford, 2-57.

De Duve C, Wattiaux R 1956. Tissue fractionation studies. VII. Release of bound hydrolases by means of triton X-100. Biochem J 63: 606-608.

Dehn PF, Schirf VR 1986. Energy metabolism in largemouth bass (Micropterus floridanus salmoides) from stressed and non-stressed environments: adaptations in the secondary stress response. Comp Biochem Physiol A Comp Physiol 84: 523-528.

Dietz AA, Lubrano T 1967. Separation and quantitation of lactic dehydrogenase isoenzymes by disc electrophoresis. Anal Biochem 20: 246-257.

el Gowhary SH, Rahmy AE, el Azzouni MZ, Nagil AI, el Medany A 1993. Oral contraceptive pills in experimental schistosomiasis mansoni: parasitological, biochemical, histopathological and ultrastructural studies. J Egypt Soc Parasitol 23: 609-619.

El Naga IF, Eissa MM, Mossallam SF, El-Halim SI 2010. Inheritance of Schistosoma mansoni infection incompatibility in Biomphalaria alexandrina snails. Mem Inst Oswaldo Cruz 105: 149-154.

El-Aasar AA, El-Merzabani MM, Zakhary NI, Farag HI, Abdeen AM, Abd El-Salam I, Mokhtar NM 1989. Biochemical and biophysical studies on schistosomal liver of mice. Egypt J Bilh 11: 19-33. 
El-Ansary A, Mohamed SM, Mohamed AM 2001. Induced changes in energy metabolism of Biomphalaria alexandrina snails using two potent plant molluscicides. Bull NRC Egypt 26: 425-439.

El-Banhawey MA, Ashry MA, EL-Ansary AK, Aly SA 2007. Effect of Curcuma longa or praziquantel on Schistosoma mansoni infected mice liver - histological and histochemical study. Indian $J$ Exp Biol 45: 877-889.

Frederiks WM, Marx F 1988. A quantitative histochemical study of 5 '-nucleotidase activity in rat liver using the lead salt method and polyvinyl alcohol. Histochem J 20: 207-214.

Frontera E, Roepstorff A, Gázquez A, Reina D, Serrano FJ, Navarrete I 2003. Immunohistochemical distribution of antigens in liver of infected and immunized pigs with Ascaris suum. Vet Parasitol 111: 9-18.

Hamed MA 2006. Excretory-secretory product of Fasciola hepatica worm protects against Schistosoma mansoni infection in mice. Indian J Exp Biol 44: 554-561.

Hamed MA 2010. Strategic control of schistosome intermediate host. Asian J Epidemiol 3: 123-140.

Hamed MA, Hetta MH 2005. Efficacy of Citrus reticulata and Mirazid in treatment of Schistosoma mansoni. Mem Inst Oswaldo Cruz 100: 771-778.

Hirsch C, Zouain CS, Alves JB, Goes AM 1997. Induction of protective immunity and modulation of granulomatous hypersensitivity in mice using PIII, an anionic fraction of Schistosoma mansoni adult worm. Parasitology 115: 21-28.

Ittiprasert W, Miller A, Myers J, Nene V, El-Sayed NM, Knight M 2010. Identification of immediate response genes dominantly expressed in juvenile resistant and susceptible Biomphalaria glabrata snails upon exposure to Schistosoma mansoni. Mol Biochem Parasitol 169: 27-39.

Ittiprasert W, Nene R, Miller A, Raghavan N, Lewis F, Hodgson J, Knight M 2009. Schistosoma mansoni infection of juvenile Biomphalaria glabrata induces a differential stress response between resistant and susceptible snails. Exp Parasitol 123: 203-211.

Ivanovici AM 1980. The adenylate energy charge in the esturaine mollusc, Pyrazus ebeninus. Laboratory studies of responses to salinity and temperature. Comp Biochem Physiol 66: 43-55.

Jaworek D, Gruber W, Bergmeyer HU 1974. Adenosine-5-diphosphate and adenosine-5-monophosphate. In HU Bergmeyer, Methods of enzymatic analysis, Verlage Chemie Wein Heim Academic Press, London, p. 2126-2131.

Jones LG, Bogitsh BJ 1979. Further observations on ultrastructural changes in hepatocytes of mice infected with Schistosoma mansoni. Z Parasitenkd 60: 185-192.

Lamprecht W, Trauschold I 1974. Determination of adenosine-5triphosphate with hexokinase and glucose-6-phosphate dehydrogenase. In HU Bergmeyer, Methods of enzymatic analysis, Verlage Chemie Wein Heim Academic Press, London, p. 2101-2109.

Maghraby SA, Shker KH, Zahran HG, El-Sherbiny M 2007. In vivo, the immunological effects of Fasciola gigantica worms homogenate mixed with saponin on mice infected with Schistosoma mansoni. J Med Sci 7: 724-731.

Mahmoud AH, Rizk MZ 2004. Free radical scavengers in susceptible/ resistant Biomphalaria alexandrina snails before and after infection. Comp Biochem Physiol C Toxicol Pharmacol 138: 523-530.

Maly IP, Toranelli M 1993. Ultrathin-layer zone electrophoresis of lactate dehydrogenase isoenzymes in microdissected liver samples. Anal Biochem 214: 379-388.
Mantawy MM, Hamed MA, Sammour EM, Sanad M 2004. Influence of Capparis spinosa and Acacia arabica on certain biochemical haemolymph parameters of Biomphalaria alexandrina. J Egypt Soc Parasitol 34: 659-677.

Mente E, Deguara S, Santos MB, Houlihan D 2003. White muscle free amino acid concentrations following feeding a maize gluten dietary protein in Atlantic salmon (Salmo salar L.). Aquaculture 225: 133-147.

Nabih I 1981. Immunological control of parasitic diseases through chemically pretreated antigens. I. Schistosomiasis. Cell Mol Biol Incl Cyto Enzymol 27: 279-282.

Olivier L, Stirewalt MA 1952. An efficient method for the exposure of mice to cercariae of Schistosoma mansoni. J Parasitol 38: 19-23.

Pellegrino J, Oliveira CA, Faria J, Cunha AS 1962. New approach to the screening of drugs in experimental schistosomiasis mansoni in mice. Am J Trop Med Hyg 11: 201-215.

Rice ME, Shelton E 1957. Comparison of the reduction of two tetrazolium salts with succinoxidase activity of tissue homogenates. J Natl Cancer Inst 18: 117-125.

Silva LM, Menezes RM, de Oliveira SA, Andrade ZA 2003. Chemotherapeutic effects on larval stages of Schistosoma mansoni during infection and re-infection of mice. Rev Soc Bras Med Trop 36: 335-341.

Smithers SR, Terry RJ 1965. The infection of laboratory hosts with cercariae of Schistosoma mansoni and the recovery of the adult worms. Parasitology 55: 695- 700.

Swanson MA 1955. Glucose-6-phosphatase from liver. In SP Colowick, NO Kaplan (eds.), Methods in enzymology, vol. II, Academic press, New York, p. 541-543.

Tanabe M, Kaneko N, Takeuchi T 1991. Schistosoma mansoni: higher free proline levels in the livers of infected mice. Exp Parasitol 72: 134-144.

Tendler M, Pinto RM, Oliveira Lima A, Gebara G, Katz N 1986. Schistosoma mansoni: vaccination with adult worm antigens. Int J Parasitol 16: 347-352.

Tielens AG, van den Heuvel JM, van Mazijk HJ, Wilson JE, Shoemaker CB 1994. The 50-kDa glucose 6-phosphate-sensitive hexokinase of Schistosoma mansoni. J Biol Chem 269: 24736-24741.

Tolba MR, Attalah A, Nabih I, Soliman AM, El-Sherbeny M 1995. Effects of irradiation and chemical treatment on Biomphalaria alexandrina antigens. J Union Arab Biol 3: 29-40.

Tornheim K, Lowenstein JM 1974. The purine nucleotide cycle. IV. Interactions with oscillations of the glycolytic pathway in muscle extracts. $J$ Biol Chem 249: 3241-3247.

Van Waarde A, Van den Thillart G, Erkelens C, Addink A, Lugtenburg J 1990. Functional coupling of glycolysis and phosphocreatine utilization in anoxic fish muscle. An in vivo 31P NMR study. J Biol Chem 265: 914-923.

Wijsman TCM 1976. Adenosine phosphates and energy charge in different tissues of Mytilus edulis L. under aerobic and anaerobic conditions. J Comp Physiol 107: 129-140.

Xu X, Zhang D, Sun W, Zhang Q, Zhang J, Xue X, Shen L, Pan W 2009. A Schistosoma japonicum chimeric protein with a novel adjuvant induced a polarized Th1 immune response and protection against liver egg burdens. BMC Infect Dis 9: 54.

Zahoor Z, Davies AJ, Kirk RS, Rollinson D, Walker AJ 2010. Larval excretory-secretory products from the parasite Schistosoma mansoni modulate HSP70 protein expression in defence cells of its snail host, Biomphalaria glabrata. Cell Stress Chaperones 15: 639-650. 